University of Tennessee Health Science Center

UTHSC Digital Commons

$12-2012$

\title{
In vitro Staining of Denture Liners and Potential for Color Correction Using Commonly Available Denture Cleansers
}

\author{
Russell D. Morrell \\ University of Tennessee Health Science Center
}

Follow this and additional works at: https://dc.uthsc.edu/dissertations

Part of the Prosthodontics and Prosthodontology Commons

\section{Recommended Citation}

Morrell, Russell D. , "In vitro Staining of Denture Liners and Potential for Color Correction Using Commonly Available Denture Cleansers" (2012). Theses and Dissertations (ETD). Paper 181. http://dx.doi.org/ 10.21007/etd.cghs.2012.0218.

This Thesis is brought to you for free and open access by the College of Graduate Health Sciences at UTHSC Digital Commons. It has been accepted for inclusion in Theses and Dissertations (ETD) by an authorized administrator of UTHSC Digital Commons. For more information, please contact jwelch30@uthsc.edu. 


\title{
In vitro Staining of Denture Liners and Potential for Color Correction Using Commonly Available Denture Cleansers
}

\author{
Abstract \\ Background: Denture liners are routinely used as part of immediate denture therapy, following surgery \\ involving edentulous tissues, and to improve the function and stability of existing removable prostheses. \\ Appropriate application of denture liners can facilitate patient comfort during prolonged therapy and prior \\ to placement of definitive restorations. However, concern has been raised regarding the susceptibility of \\ common denture liners to agent-induced color change which, in turn, adversely impacts the esthetic \\ appeal of the associated removable prosthesis.
}

Objective: The purpose of the study was to evaluate the color stability of denture liners exposed to commonly encountered food stains and commonly used denture cleaning solutions.

Method: Disk samples, $20 \mathrm{~mm}$ in diameter, were fabricated consisting of two layers: a $2 \mathrm{~mm}$ thick denture base resin layer (Lucitone 199®, Dentsply, York, PA) and a $2 \mathrm{~mm}$ thick denture liner layer. Three groups of 45 samples were prepared, each group representing a different denture liner, including: a silicone liner group (Silk Line ${ }^{T M}, J$. Morita USA, Irvine, CA); a methyl methacrylate-free resin liner group (GC Reline ${ }^{T M}, \mathrm{GC}$ America, Inc., Alsip, IL); and a polyethyl methacrylate resin liner group (Kooliner ${ }^{\mathrm{TM}}$, GC America, Inc., Alsip, IL). An equal number of samples from each liner group were assigned to one of three staining agents, including: cola (Coca-Cola Company, Atlanta, GA); grape juice, and coffee. Following a $12 \mathrm{hr}$. staining cycle, samples from each staining agent were equally distributed to one of three soaking fluids for $12 \mathrm{hrs}$., including: two different effervescing cleaning agents (Efferdent, New Brunswick, NJ, and Polydent, Philadelphia, PA) and distilled water. This stain-soak cycle was continuously repeated, changing the soaking solution every day. Denture liner color measurements were made (Labscan XE Spectrocolorimeter, Hunter Associates Laboratory, Reston, VA) on the 1st, 15th, 30th, 45th, and 60th day and color differences $(\Delta \mathrm{E})$ were calculated.

Results: Statistical analysis revealed that all liners experienced substantial color change from baseline to 2-weeks. From 2-weeks to 8-weeks, no statistically significance color change was recorded for any of the staining agent-soaking solution combinations. When comparing results for the different liner types, the silicone liner demonstrated significantly increased overall staining as compared to the resin liners.

Conclusions: This study suggests: (1) exposing denture liners investigated to the staining agents used resulted in clinically discernible color changes; (2) use of denture cleansers had little beneficial effect on liner discoloration as compared to immersion in water; (3) following initial liner color change at two weeks, little to no further color change was noted regardless of staining agent or soaking fluid; (4) the silicone liner demonstrated the greatest color change when compared to the resin liners; and (5) conventional denture cleansers were statistically similar $(p>0.05)$ to water with respect to the improvement of discolorations evaluated in this study.

\section{Document Type}

Thesis

\section{Degree Name}

Master of Dental Science (MDS)

\section{Program}

Prosthodontics 


\section{Research Advisor}

Laura A. Darnell, DMD, PhD

\section{Keywords}

Denture liners, Color change, Cleansers, Staining agents

\section{Subject Categories}

Dentistry | Medicine and Health Sciences | Prosthodontics and Prosthodontology 


\title{
In vitro Staining of Denture Liners and Potential for Color Correction Using
} Commonly Available Denture Cleansers

\author{
A Thesis \\ Presented for \\ The Graduate Studies Council \\ The University of Tennessee \\ Health Science Center
}

\begin{abstract}
In Partial Fulfillment
Of the Requirements for the Degree

Master of Dental Science

From The University of Tennessee
\end{abstract}

By

Russell D Morrell

December 2012 
Copyright (C) 2012 by Russell D Morrell.

All rights reserved. 


\section{ACKNOWLEDGEMENTS}

I would like to express my gratitude to everyone who has helped me in my endeavor to complete a Master of Dental Science in Prosthodontics. I am grateful to Dr. Laura Darnell, Tyler Holley, and Tiffany Stuart; without their contributions this research project would not have been possible. I would also like to thank my committee members, Drs. David Cagna, Greg Paprocki, Mark Scarbecz, Tony Wicks, and Robert Brandt for their advice and support. 


\begin{abstract}
Background: Denture liners are routinely used as part of immediate denture therapy, following surgery involving edentulous tissues, and to improve the function and stability of existing removable prostheses. Appropriate application of denture liners can facilitate patient comfort during prolonged therapy and prior to placement of definitive restorations. However, concern has been raised regarding the susceptibility of common denture liners to agent-induced color change which, in turn, adversely impacts the esthetic appeal of the associated removable prosthesis.
\end{abstract}

Objective: The purpose of the study was to evaluate the color stability of denture liners exposed to commonly encountered food stains and commonly used denture cleaning solutions.

Method: Disk samples, $20 \mathrm{~mm}$ in diameter, were fabricated consisting of two layers: a $2 \mathrm{~mm}$ thick denture base resin layer (Lucitone $199^{\circledR}$, Dentsply, York, PA) and a $2 \mathrm{~mm}$ thick denture liner layer. Three groups of 45 samples were prepared, each group representing a different denture liner, including: a silicone liner group (Silk Line ${ }^{\mathrm{TM}}, \mathrm{J}$. Morita USA, Irvine, CA); a methyl methacrylate-free resin liner group (GC Reline ${ }^{\mathrm{TM}}$, GC America, Inc., Alsip, IL); and a polyethyl methacrylate resin liner group (Kooliner ${ }^{\mathrm{T}}$, GC America, Inc., Alsip, IL). An equal number of samples from each liner group were assigned to one of three staining agents, including: cola (Coca-Cola Company, Atlanta, GA); grape juice, and coffee. Following a $12 \mathrm{hr}$. staining cycle, samples from each staining agent were equally distributed to one of three soaking fluids for $12 \mathrm{hrs}$., including: two different effervescing cleaning agents (Efferdent, New Brunswick, NJ, and Polydent, Philadelphia, PA) and distilled water. This stain-soak cycle was continuously repeated, changing the soaking solution every day. Denture liner color measurements were made (Labscan XE Spectrocolorimeter, Hunter Associates Laboratory, Reston, VA) on the $1^{\text {st }}, 15^{\text {th }}, 30^{\text {th }}, 45^{\text {th }}$, and $60^{\text {th }}$ day and color differences $(\Delta \mathrm{E})$ were calculated.

Results: Statistical analysis revealed that all liners experienced substantial color change from baseline to 15 days. From 15 days to 60 days, no statistically significance color change was recorded for any of the staining agent-soaking solution combinations. When comparing results for the different liner types, the silicone liner demonstrated significantly increased overall staining as compared to the resin liners.

Conclusions: This study suggests: (1) exposing denture liners investigated to the staining agents used resulted in clinically discernible color changes; (2) use of denture cleansers had little beneficial effect on liner discoloration as compared to immersion in water; (3) following initial liner color change at two weeks, little to no further color change was noted regardless of staining agent or soaking fluid; (4) the silicone liner demonstrated the greatest color change when compared to the resin liners; and (5) conventional denture cleansers were statistically similar $(p>0.05)$ to water with respect to the improvement of discolorations evaluated in this study. 


\section{TABLE OF CONTENTS}

CHAPTER 1. INTRODUCTION AND BACKGROUND ................................................1

CHAPTER 2. REVIEW OF LITERATURE ...............................................................

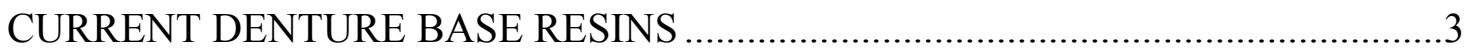

POLYMETHYL METHACRYLATE (PMMA) CHEMISTRY ……….........................

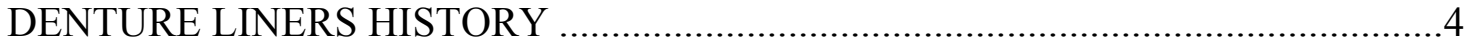

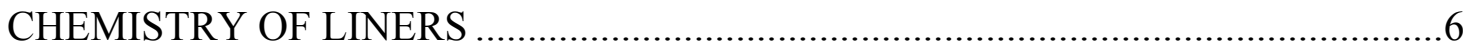

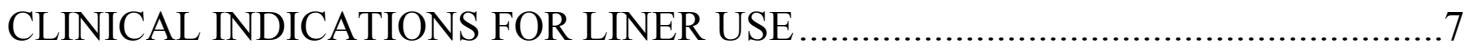

Immediate Complete Dentures ........................................................................

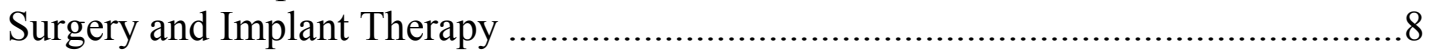

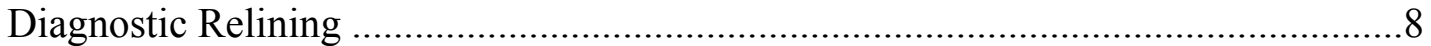

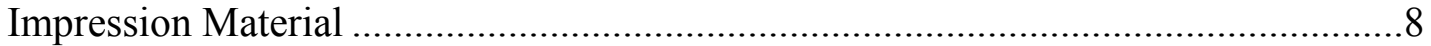

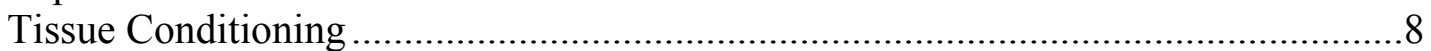

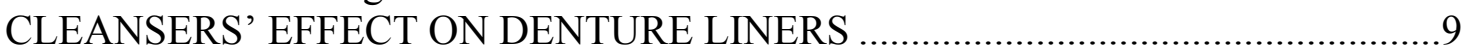

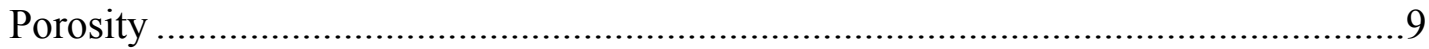

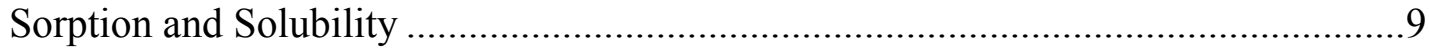

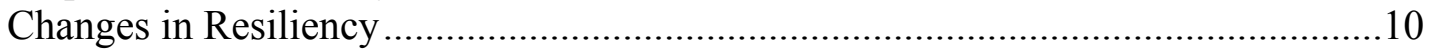

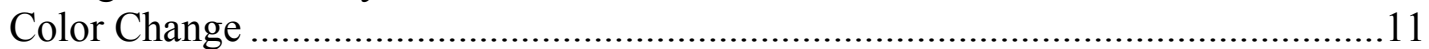

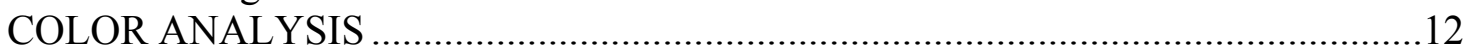

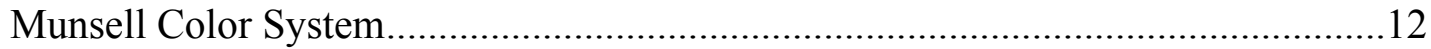

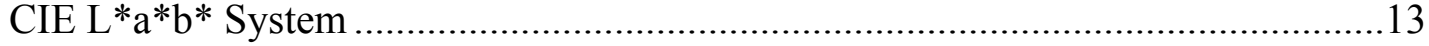

CHAPTER 3. MATERIALS AND METHODS...............................................................14

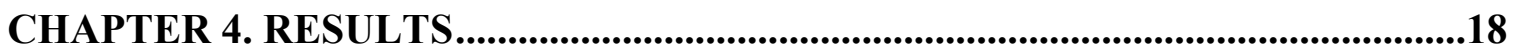

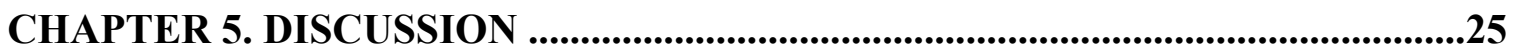

CHAPTER 6. CONCLUSIONS..........................................................................................27

CHAPTER 7. LIMITATIONS AND FUTURE APPLICATIONS ...............................28

LIST OF REFERENCES..............................................................................................29

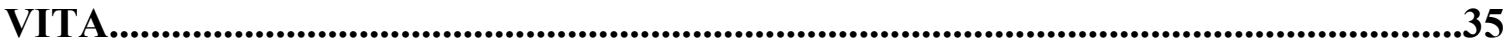




\section{LIST OF TABLES}

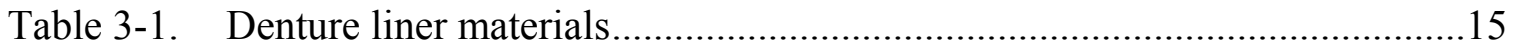

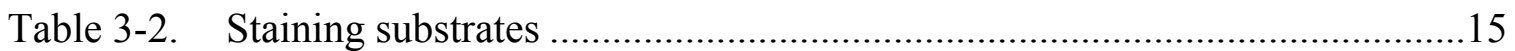

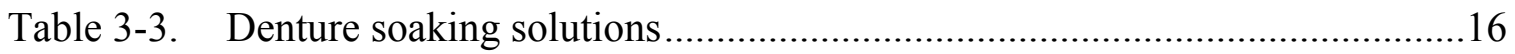

Table 3-4. Denture liners subdivided into sample groups labeled 1-45 for each staining solution and soaking solution used on that material.....................16

Table 4-1. Mean and standard deviation (SD) of baseline cielab color measurements of each denture liner before treatment.

Table 4-2. Mean color changes $(\Delta \mathrm{E})$ of denture liners, stain agent, and cleanser over the time of the study of 60 days

Table 4-3. Three-way ANOVA table for mean color change $(\Delta \mathrm{E})$ from baseline measurements and at 60 days into the study 


\section{LIST OF FIGURES}

Figure 4-1. Mean color changes $(\Delta \mathrm{E})$ of denture liners, stain agents, and soaking agents at first reading (15 days) until the end of the study (60 days)

Figure 4-2. Mean color change ( $\Delta \mathrm{E})$ at 15 and 60 days with $95 \%$ confidence intervals by soaking agent type

Figure 4-3 Mean color change $(\Delta \mathrm{E})$ at 15 and 60 days with $95 \%$ confidence intervals by stain type.

Figure 4-4. Mean color change $(\Delta \mathrm{E})$ at 15 and 60 days with $95 \%$ confidence intervals by liner type 


\section{CHAPTER 1. INTRODUCTION AND BACKGROUND}

People have been searching for methods of tooth replacement for over 3000 years. Materials such as wood, ivory, metal, animal bone and porcelain have been described in the literature as examples for tooth replacement (Murray \& Darvell, 1993; Phoenix, 1996). In the mid-1940s a major breakthrough was made in denture base fabrication with the introduction of Poly(methyl methacrylate) (PMMA) acrylic for dental use (Peyton, 1975). Since this time PMMA acrylic has become the most popular material for the formation of removable prosthesis in dentistry. However, shortcomings with the denture material are still present when dealing with the replacement of missing teeth (Wright, 1994; Garcia \& Jones, 2004; Hill \& Rubel, 2011).

Investigators worked on trying to alleviate these shortcomings of acrylic denture bases without much success. In the early 1960 s, Storer stated that the introduction of resilient medical grade silicone liners incorporated into existing denture bases was a big step forward in helping to resolve these common problems in prosthodontics (Sultana, 1991). This silicone material could cushion the patients denture base during soft and hard oral tissue healing, allowing the patient to wear their dentures comfortably. Long term clinical use was limited with this liner material due to de-bonding and propagation of candidal flora (Robinson, 1963; Burns et al., 1987).

Continued improvement in liners have given the dental professional new ways to combat physical, mechanical, and esthetical complications associated with dentures. Patients, who could not tolerate the discomfort associated with conventional removable prosthesis, are able to gain support and comfort from the liners. With the increased popularity of implants in the dental community, patients have been given new options for treatment, especially edentulous patients (Garcia \& Jones, 2004).

The problem for treating dentists is trying to understand what liner materials will best serve their patients during treatment. PMMA resin or silicone compounds are usually the preferred choices in liner materials. The limiting factors with these denture liner materials are; color stability, long-term resiliency, porosity, and cleansability (Wright, 1984). These disadvantages are because denture liners were never intended to be a definitive restoration but simply a temporary adjunct to existing dentures.

Multiple studies have looked at color stability of denture liners that have been stained with food colorants and then soaked in denture cleansers (Ergun \& Nagas, 2007; Oguz et al., 2007; Sarac et al., 2007). Color stability is an important clinical property for all dental restorative materials and is a criterion that provides information on the serviceability of these materials. Visual aspects of color changes can be left to the human eye. The eye may not notice minute changes due to fatigue, lighting conditions, aging, and illuminating positions (Kuchni \& Marcus, 1979). To help eliminate these variables, researchers use a spectrocolorimeter in gaining accurate color changes (Yap et al., 1999). 
The purpose of this study was to examine the effects of cleaning solutions on the color stability of denture base liners the hypotheses tested were:

- Subjecting base-liner samples to a repetitive cycle of stains/cleansers will result in color change.

- Color change of base-liner samples subjected to a repetitive cycle of stains/cleansers will continue to increase over time.

- Color change of base-liner samples subjected to a repetitive cycle of stains/cleansers will result in less color change than stained samples not subjected to cleansers.

These hypotheses were tested through the following specific aims:

- Specific Aim 1: To determine the efficacy of different staining agents on silicone- and PMMA-based liners.

- Specific Aim 2: To determine the color changes over time when liners are exposed to staining agents and cleansers.

- Specific Aim 3: To determine the efficacy of the different cleansers as compared to water. 


\section{CHAPTER 2. REVIEW OF LITERATURE}

Many materials have been used over the years to fabricate denture bases. As described earlier, man used objects that could be easily found in nature for the fabrication of a removable prosthesis (Murray \& Darvell, 1993; Phoenix, 1996; Patrick et al., 2006; Khindria et al., 2009). The earliest example of a complete set of denture dates from around 1500 A.D. in Switzerland. Over the next few centuries dentures were usually reserved for only the wealthy, due to detailed work involved in hand crafting these esthetic devices (Murray \& Darvell, 1993). In the mid-1800s Charles Goodyear developed vulcanized rubber, which significantly reduced the cost of dentures (Khindria et al., 2009). Due to patent and royalty issues, vulcanite was not freely available to dentists. When these patents expired, due to the death of Josiah Bacon in 1879, vulcanite became the material of choice for denture bases until the mid-1900s (Murray \& Darvell, 1993; Rueggeberg, 2002).

\section{CURRENT DENTURE BASE RESINS}

Around 1937 polymethyl methacrylate (PMMA) resin was clinically evaluated by Wright, and found to fulfill virtually all requirements of the ideal denture base material (Peyton, 1975; Murray \& Darvell, 1993). Sweeney reported that the properties of this material offered a substantial improvement over earlier materials (Sweeney, 1938; Murray \& Darvell, 1993) and by 1946 PMMA resin was used in almost 95\% of dentures (Peyton, 1975; Murray \& Darvell, 1993). PMMA resin had many advantages over other materials due to its color stability that could be used to match gingiva, teeth, was easy to repair, could chemically bond with teeth made from the same material, and was inexpensive (Murray \& Darvell, 1993).

Currently, most PMMA resin denture base materials are supplied as a powderliquid system. When mixed, they form a workable mass that can be introduced into a mold cavity and polymerized (Phoenix, 1996). Denture resins are offered in various processing methods: heat-activated resins, chemically-activated resins, and lightactivated resins, with heat-activated being the most common (Phoenix, 1996; Anusavice, 2003).

Since the introduction of PMMA into the dental community researchers have aimed at trying to improve the material. These improvements have focused on: 1) gaining greater strength, improving dimensional stability, improving resistance to candidal infiltration, and reducing residual monomers after processing (Dhir et al., 2007). Excess monomer will always remain in the denture base resin, but reducing these monomer levels can help reduce irritation and allergies in the patient's tissue (Leggat \& Kedjarune, 2003; Lung \& Darvell, 2005). Leaving the newly processed dentures in a water bath for 24 hours has been advised to help reduce free monomers, but a study by Jorge et al. (2007) showed this technique had little effect upon reducing the cytotoxicity levels. 


\section{POLYMETHYL METHACRYLATE (PMMA) CHEMISTRY}

Pure PMMA is a colorless, transparent solid. For use in dental applications, the polymer may be tinted to provide almost any shade and degree of translucency (Brauer, 1966; Anusavice, 2003). PMMA progresses through a number of reactions, including initiation, propagation, chain transfer, termination, and tacticity, before being formed. As previously noted, PMMA resin systems contain a powder and liquid component. The powder consists of fine pink prepolymerized spheres of poly(methyl methacrylate) and benzoyl peroxide. The benzoyl peroxide starts the initiation step in the reaction. The liquid consists of nonpolymerized methyl methacrylate and hydroquinone. Cross-linking agents are also placed into the liquid, which can help in the formation of polymer chains (Anusavice, 2003).

When the powder and liquid components are mixed accordingly the resulting mass of material will pass through five stages of polymerization (sandy, stringy, doughlike, rubbery, and stiff) (Anusavice, 2003). These polymerization reactions do not usually result in complete exhaustion of the monomer, as previous noted. Once the stiff stage has been reached the newly formed PMMA resin base is ready to be adjusted and polished for delivery to the patient.

\section{DENTURE LINERS HISTORY}

The first denture liner was used by Twitchell in 1869 and was made of a natural soft rubber (Bates \& Smith, 1965). Little research is available on liners before the 1950s, with many of the publications relying on anecdotal information and case reports (Garcia \& Jones, 2004).

In the 1940s vellum, a soft natural rubber, was used with vulcanite for obturators and for lining mandibular complete dentures. Due to its high absorption the lining became foul and ill fitting (Lammie \& Storer, 1958). The material also swelled, which caused it to result in a bond failure with the denture base (Sultana, 1991).

In 1942, Matthews introduced a plasticized polyvinyl chloride (PVC) as one of the first lining materials used with acrylic resin dentures (Sultana, 1991). The PVC material was in the form of a powder and liquid (di-butyl phthalate) that formed a paste when mixed. The results were well received, as the material did not swell, but the material would harden over time and become brittle (Sultana, 1991). In 1962, Storer found that PVC material would not last more than a year. He stated that lactic acid, even in weak solutions, would facilitate the loss of plasticizer from the vinyl resin, thus causing it to harden. He recommended the use of dioctyl phthalate as a plasticizer for PVC due to its slower leaching into the oral fluids, thus allowing the material to remain soft longer (Sultana, 1991). 
Lammie and Storer published a summary of observations on different denture liner materials and classified the processed liner materials as follows: (1) natural rubber, (2) polyvinyl chloride, (3) polyvinyl acetate, (4) methyl methacrylate copolymer, and (5) silicone (Lammie \& Storer, 1958). Nelson (1948) used butyl phthalate butyl glycolate as a plasticizer for vinyl chloroacetate. He stated that this combination would increase the bond strength between the liner and the denture base and would remain soft for a longer period of time. However, Lammie \& Storer showed that this material became hard due to loss of plasticizer after several months, and became stained and cracked in the mouth (1958).

In 1961 Wichterle and Lin developed a hydrophilic gel based on glycol methacrylate ester chemistry. The material was hard when set but when immersed into water became soft and then swelled to a final water content of 37\%. This material failed to gain clinical use due to these volumetric changes (Klinment et al., 1968).

Chemically activated and heat processed polydimethyl siloxanes were reported by Storer in 1962. These chemically activated silicone rubbers were satisfactory in clinical use. Resilience was the main advantage of this material, sometimes being maintained for up to five years, but the silicone rubbers lost surface detail through abrasion and had low bond strength (Sultana, 1991). Heat activated silicone rubber liners were processed separately from the denture base and then cemented to it (Robinson, 1963). Molloplast$\mathrm{B}$, a silicone heat activated silicone rubber, was shown to have superior bond strength with acrylic resins and was shown to be serviceable for up to six years in $92.5 \%$ of the dentures (Schmidt \& Smith, 1983; Sultana, 1991). Molloplast-B is still available today for use (Garcia \& Jones, 2004). Permanently resilient medical grade silicone as a denture base was labeled a big step forward in helping resolve common problems in prosthodontics (Robinson, 1963). The lack of adhesion to acrylic denture bases and growth of candidal flora limited its use (Barnhart, 1964). When heat was added to the material during processing, the success rate as a denture base liner increased dramatically (Wright, 1981; Schmidt \& Smith, 1983).

In 1982, Parker and Braden developed a material that had polymerizable plasticizer. They wanted to avoid hardening of the materials by keeping the plasticizer from leaching out. Major problems with this material were that it promoted the growth of candidal flora and de-bonded very easily (Burns et al., 1987). They tried to develop another material, but again this failed during Wright's clinical trials (Wright, 1981). A fluoropolymer soft liner, which consisted of several copolymers, was developed in 1984 in Japan. The material was chemically stable and showed good resistance to solvents and abrasion. It also bonded very well to acrylic resins (Hayakawa et al., 1984).

The International Organization for Standardization (ISO) has issued two international standards related to liner materials: (ISO 10139-1:1991): 1) lining materials for removable dentures-Part 1: short-term materials and soft lining materials for removable dentures (ISO, 1991) and 2) lining materials for removable dentures-Part 2: materials for long-term use (ISO, 1999). A short-term liner is one that is used intraorally 
for up to 30 days. A long-term liner is one that maintains softness and elasticity for more than 30 days (Garcia \& Jones, 2004).

No required essential properties for liners have yet to be established, although studies have looked at the hardness, solubility, tensile strength, elongation, tear resistance, tear energy, color stability, and resistance to bacterial growth. The only data produced about liners relates to what liner types may be applied to certain situations in the oral rehabilitation process, as various liners differ significantly in their physical and mechanical properties (Dootz et al., 1992).

\section{CHEMISTRY OF LINERS}

Acrylic resin-based liners, both the heat activated and chemically activated, consist of powder and liquid components. The powder has poly(ethyl or methyl) methacrylate, and sometimes copolymers, while the liquid contains methyl methacrylate monomer and plasticizers that are added to lower the glass transition temperature. The distribution of the large plasticizer molecules minimizes entanglement of polymer chains, which allows individual chains to slide by one another, keeping the liner from fully hardening. The liquids used do not contain acrylic monomers (Craig \& Gibbons, 1961; Anusavice, 2003).

Reported plasticizers consist of butyl phthalate, butyl glycolate, dibutyl phthalate, ethyl acetate, benzyl benzoate, butyl benzoyl phthalate, and dibutyl sebacate (Braden, 1970; McCabe, 1976; Jones et al., 1989). The overall chemistry of acrylic based liners is very similar to that of PMMA acrylic denture bases, except for the size of the plasticizers used and the lack of monomers in the liquids.

Liners used for tissue conditioning are like acrylic resins in that they have a twocomponent powder and liquid system. The powder is a polyethyl methacrylate and/or copolymers, while the liquid is a mixture of ethyl alcohol as solvent and dibutyl phthalate as plasticizer (Winkler, 1989).

Silicone liner materials are similar in composition to the silicone impression materials used in dentistry. They are mixed inorganic-organic polymers that have the chemical formula $\left[\mathrm{R}_{2} \mathrm{SiO}\right] \mathrm{n}$, where $\mathrm{R}$ is an organic group such as methyl, ethyl, or phenyl. Along with this is an inorganic silicon-oxygen backbone [-Si-O-Si-O-] with organic side groups attached to the silicon atoms. By varying the -Si-O- chain lengths, side groups, and cross linking, silicones can vary in consistency from liquid to a hard plastic (Anusavice, 2003). Silicone denture liners are basically polymers of dimethylsiloxane. Poly(dimethylsiloxane) is a viscous liquid, which can be cross-linked to give rubber a good elastic property. The cross-linking agent is usually an alkyl-silane (silicate) and the reaction is catalyzed by an organo-metal salt such as tinoctoate or benzoyl peroxide (McCabe, 1976). Silicones are not dependent on leachable plasticizers and remain elastic for longer periods of time (Anusavice, 2003; Munksgaard, 2004). These liners cannot bind to the acrylic denture base; however, the use of an adhesive can 
overcome this limitation, which was shown to be a method of failure (Dogan et al., 2006).

\section{CLINICAL INDICATIONS FOR LINER USE}

The American Dental Association's Guide to Dental Materials and Devices recommends that liners be considered only as temporary expedients. These liner materials may be selected for the treatment of the following conditions (Zarb et al., 1989; Christensen, 1995; Hayakawa et al., 2000; Hill \& Rubel, 2011):

- poor stability of denture

- inadequate retention of denture

- reduction of vertical dimension

- degradation of the denture base

- improper extension of borders into the muccobuccal fold regions

- mucosal irritations

- atrophic ridges

- boney undercuts

- denture(s) opposing natural teeth

- reduced thickness and viscoelasticity of the mucosa

- pain from gingival irritation

- maxillofacial defects

- traumatic or pathologic tissue loss

- reline of an existing denture

Liners can also assist the dental practitioner in a multitude of clinical situations. These additional uses of liners will be examined in more detail next.

\section{Immediate Complete Dentures}

When fabricating immediate complete dentures patient's undergoing multiple extractions, estimates in the shape of the remaining alveolus are made. Phoenix discussed a detailed way to calculate potential dimensions of the remaining ridge before fabricating an immediate denture in his article (2008). Regardless of how much preparation has taken place beforehand, the newly made denture does not always fit on the day of delivery. Adding a soft liner to the denture base can help fill in the excessive voids created from the extractions. This helps keep the denture in a normal relationship with the tissue, which adds to the patients comfort during healing (Winkler, 1989; Kawano et al., 1999). Researchers have advised that if using a soft liner in an immediate denture, that the material be replaced periodically. After six months to a year, or when the sockets have filled in with bone, the liner should be replaced with a hardliner. (Winkler, 1989; Garcia \& Jones, 2004). 


\section{Surgery and Implant Therapy}

Preprosthetic surgery involving changes in the patient's alveolar architecture, such as removal of exostosis, tori removal, and tuberosity reductions. These changes can limit the patient's abilities to wear their existing dentures comfortably. The use of liners can help improve denture adaptation to the supporting tissues. This effect can help reducing edema and controlling postsurgical bleeding, which helps in wound healing (Wendt, 1974; Winkler, 1989; Garcia \& Jones, 2004). Liners have been used in implant therapy to help distribute pressure of the prosthesis over a broad area of supporting tissues, allowing the implant and the tissue around the implant to heal properly (Albrektsson \& Zarb, 1989: Garcia \& Jones, 2004). During the healing phase of implant therapy, softer based liners can engage healing abutments which helps the interim prosthesis with retention. To keep undue forces from being transmitted to the implants, researchers have recommended frequent replacement of the liner (Garcia \& Jones, 2004; De Almeida et al., 2011; Kim et al., 2011).

\section{Diagnostic Relining}

Liners have been indicated for use as diagnostic purposes. This method can help the dentist evaluate the patient's occlusal vertical dimension, re-establish esthetics, or evaluate where new acrylic needs to be added to an existing denture. This technique can also be used to determine the patient's commitment to oral hygiene before a financial obligation is made towards definitive treatment (Garcia \& Jones, 2004).

\section{Impression Material}

To coincide with using liners for diagnostic purposes, dental practitioners have recommended using liners to assist in making dental impressions. Due to their delayed setting attributes, liners can serve as a good material for border-molding and impression techniques (Sarka, 1996). This delay in the material allows the dentist to capture the muscles and attachments to their full extent during border-molding and functional impressions (Qudah et al., 1990; Garcia \& Jones, 2004; Hill \& Rubel, 2011; Wegner et al., 2011).

\section{Tissue Conditioning}

Swollen, abused tissue is a common obstacle dentist's face when patients present for a denture adjustment, a repair, or a new denture. Detailed inspection of the denture is needed for diagnosis of the offending problem. Once this problem has been eliminated, a soft lining agent can be applied to facilitate healing of the tissue under the prosthesis. This material is very soft and comforting to the tissue, and can help in stabilizing the denture upon the supporting tissue surface (Qudah et al., 1990). Initially the material is very soft, but gradually becomes harder with time. This helps to condition the tissue and 
assist in healing. Due to the nature of the material it is only intended for short term use, typically one to two weeks, but up to three weeks in some cases (Anusavice, 2003). Since this material is harder to keep clean, due to its fragile nature, the tendency for bacterial and fungi collection is increased. Nystatin can be incorporated into the liner as an effective fungal growth inhibitor (Thomas \& Nutt, 1978), but regular replacement of the liner is usually the best solution.

\section{CLEANSERS' EFFECT ON DENTURE LINERS}

Liners are subjected to numerous materials on a daily bases that can influence the properties of the material. These liners are known to change color from the intake of fluids and food (Qudah et al., 1990). The difficulty in cleaning denture liners, especially soft liners, remains a disadvantage of these materials. Common daily methods for cleaning dentures include brushing and use of immersion cleansers. Denture cleansers are widely used to prevent colonization by candida albicans and prevent plaque formation. The solutions used for denture cleaning can be divided according to their chemical compositions or made of action: alkaline peroxide, alkaline hypochlorites, acids, disinfectants, mouth rinses for dentures, and enzymes (Sarac et al. 2007). Efferdent and Polident both contain sodium perborate, which is a source of hydrogen peroxide. When these tablets dissolve in water the sodium perborate dissolves to form an alkaline peroxide solution. This solution releases oxygen, which loosen debris by mechanical means (Hong et al., 2009). This reaction has shown to cause structural changes in the liners, which will be examined in further detail.

\section{Porosity}

Wright (1984) found that porosity or surface roughness is the second most common reason for liner replacement. Brown (1988) showed that using cleansers with alkaline peroxides (Efferdent) could cause surface and subsurface bubbling. He advised using plain soap and water to clean dentures with liners and avoiding abrasive cleansers.

Nikawa et al. (1994) evaluated the effects of denture cleansers on direct liners. They studied 12 cleansers and six liners and examined the deterioration of the liners as well as the porosity and distortion of the liners after immersion into the cleansers for a total of 14 days. The findings suggested that all cleansers examined deteriorated the liners to some extent depending on the immersion time and the combination of cleanser and liner used.

\section{Sorption and Solubility}

Kawano et al. (1994) tested 12 denture liners with different chemical compositions against the ADA specification 12 for denture base polymers. The samples

were immersed in distilled water for seven days then weighed. This was repeated for one 
year, with one, three, and six-month measurements. They found that only one material (Novus) met the ADA specifications on solubility of $0.04 \mathrm{mg} / \mathrm{cm}^{2}$ after one week. Two materials met the sorption specs of $0.08 \mathrm{mg} / \mathrm{cm}^{2}$ after one year of testing. High sorption and solubility can have significant effects on the liner's longevity, due to distortion, color change, debonding, and support of bacteria.

Five lab-processed liners were immersed in artificial saliva, distilled water, and cleansers for a total of 16 weeks to test sorption and solubility. The samples examined after one, four and 16 weeks. Each sample was dried and then the disks were weighed using an electronic precision balance. The disks were then desiccated until a constant weight was obtained. Once achieved, the researchers calculated percentages of sorption and solubility. The rate at which the materials absorbed water or lost soluble components varied considerably with the type of material, plasticizer amount, and solution in which they were immersed. All linings, other than Mollaplast-B showed higher solubility in artificial saliva than water. With the changes in solubility, hardness and color change of the liners were also affected, but this change depended on the immersion time and kind of liner (Yanikoglu \& Duymus, 2004).

\section{Changes in Resiliency}

Long-term elasticity is one of the desirable properties of denture liners. The loss in this elasticity can result in higher forces being delivered to the underlying mucosa. Parr and Rueggeberg (2002) looked at chemically activated and heat activated liners in vitro by letting the liners examined sit in distilled water for one year. Measurements were made at one day, one week, one month, six months, and one year. A total of 96 samples were tested; at the end of the study the hardness of the heat activated liners were significantly greater than the chemically activated liners. The higher processing temperatures of the heat activated liners show a more complete polymerization reaction, thus a harder polymer network is formed (Parr \& Rueggeberg, 2002).

Olivera et al. (2006) showed when liners were immersed into denture cleansing compounds (Efferdent and Alkaline Hypochlorite), Sofreliner and Luci Sof hardened significantly after 360 immersions cycles. They attributed this to continued polymerization of the materials, as cited by Dootz et al. (1992). When exposing the liners to another 360 immersion cycles, the materials decreased in hardness, and approached the initial hardness mean values. The liners tested were silicone based heat and chemically activated materials. Silicone liners contain fillers and not plasticizers, and the absorption of water into the fillers could have led to this softness increase after the initial 360 immersions. Molloplast-B was shown to have no change in hardness values during the immersion cycles into the denture cleansing compounds. The hypochlorite cleansing compound caused a marked loss of color in all the materials tested; however, the change was slight and may not be relevant clinically. 


\section{Color Change}

Goll et al. (1983) analyzed the effects of nine different cleansers on eight different liners. Liners were immersed in the cleansers for one month. The cleansers were changed daily to simulate soaking them overnight for a period of three months. The white and clear liners showed color stability during the 30 days of immersion in the cleansers. The two colored liners (due to added color pigments) showed marked color fading during the same time period. The investigators emphasized that different cleanser formulations, water temperatures, and $\mathrm{pH}$ of the solutions can influence the effect of the cleansers on the liners. Shotwell et al. (1992) evaluated multiple liners by using an accelerated aging chamber. The weather chamber was kept at $110^{\circ} \mathrm{F}$ and $90 \%$ relative humidity, with intermittent distilled water sprayed every 102 minutes for 18 minutes at a time. This process was performed for 100 hours. When these materials were exposed to this accelerated aging test, liners that contained more color pigment materials showed more color change than those that contained little or no color pigments (Shotwell et al., 1992).

The previous two studies looked color changes by exposure to cleansers and aging. Oguz et al., (2006) examined the effects of liners stained by coffee and tea. They measured the samples at one, three, nine, twenty-four, forty-eight, and 96 hours, and then cleansed them with soap. All specimens immersed in the coffee solution experienced greater amounts of stain when compared to those immersed in tea. These results occurred regardless of liner type. Heat-activated and chemically activated silicone liners were more resistant to staining than chemically activated acrylic based liners (2006). Jin et al., (2003) found the same results in their study that looked at chemically activated and heat-activated silicone liners. A study showed that when stained with coffee, the silicone liners had greater discoloration than the other three heat-activated acrylic resins (Lai et al., 2003).

Sarac et al., (2007) looked at the effectiveness of cleansers on liners stained with food colorants to determine the color change in the liners. Acrylic-based liners and silicone-based liners were immersed in staining solutions for 14 hours a day, then rinsed and color was measured. The samples were then allowed to sit in cleaning solution for eight hours, and then rinsed again, followed by a color measurement. This was repeated 12 times to simulate a three-month usage of the liners. Measurement assessments were made at the $4^{\text {th }}, 8^{\text {th }}$, and $12^{\text {th }}$ cycle. The results showed that silicone liners appeared to be more resistant to staining. Fittydent was more effective than Curadent in removing discoloration of colored liners. The liners were found to be stable over the course of the study with the use of the cleansers (Sarac et al., 2007).

A clinical study of 20 patients looked at two long-term silicone-based liners, Molloplast-B and an experimental liner. Two dentures, each with a testing liner, were fabricated for each patient. The patients were instructed to wear each denture for six months, and given instructions to keep a detailed journal of their uses and cleaning methods/histories. Measurements were assessed at baseline, three months and six months for each material. Color was measured in three different areas of the liner. Patients 
compliance in reporting increased for both materials over the six months and color change was significant from baseline to three months and for baseline to six months, but not as significant from three months to six months (Villar, 2003).

When evaluating all the influences that denture cleansers have on the physical characteristics of liners, no specific stance on recommendations has been taken in the dental community. Brown (1988) stated that patients should use soap instead of denture cleansers, due to the delicate nature on the liners. A potential reason for this lack of stance may be the fact that limited research has been performed on the direct effects of denture cleansers on liners. Reasons for this can only be speculated, but potential causes could range from: 1) difficulty of conducting in vivo studies, 2) difficulty in assessing the causative factors of failure, and 3) the ease of replacing liners if they begin to fail.

\section{COLOR ANALYSIS}

Many studies examine color in dental materials. Studies have focused on how to select colors, what colors patients prefer, and what causes color change. Methods for reading color variations needs to be used in all these instances. Below are two of the most commonly used systems for evaluating color in dentistry.

\section{Munsell Color System}

In 1905 Munsell published A Color Notation, which was intended to teach his students about color by using a decimal notation instead of color names. The original publication was revised and published again in 1929 in Munsell Book of Color, and an extensive set of experiments was carried out by the Optical Society of America in the 1940s (Nickerson, 1976). Munsell's system consisted of three independent dimensions, hue, value, and chroma. He determined the spacing of colors along these dimensions by taking measurements of human visual responses. In each dimension, the colors are as close to perceptually uniform as he could make them, which made the resulting shape quite irregular (Munsell, 1912). This method is one of the most widely used systems in the selection of porcelain and resin based restorations in dentistry.

Limitations have been noted on using the Munsell's system for color evaluation. "While Munsell colors provide a very useful set of samples frequently used in color research, Munsell wavelength spectra are not necessarily typical of many naturally occurring colors. The mitigating factor is that Munsell colors are perceptually equivalent (metameric) to natural colors with the same colorimetric parameters and thus are useful in color naming research." as stated by Buchsbaum \& Bloch (2002). For example, there may be relatively fewer blues in nature than their number in the Munsell collection. The influence of human error is another limiting factor in this system. With respect to human observation, color determination is dependent on, previous eye exposure, object and illuminant position relative to the observer and to each other, and on the color 
characteristics of the illuminant. Individuals vary on their ability to color match from time to time as well (Johnston \& Kao, 1989).

\section{CIE L*a*b* System}

With the creation of the CIE L*a*b* color system by the Commission Internationale de l'Eclairage in 1976, more objective measurements of color could be performed by utilizing electronic measuring devices, removing as much human error as possible (Central de la CIE, 2004).

The CIE L*a*b* represents the lightness of the color. The $\mathrm{L}^{*}$ stands for the luminosity dimension ranging from 0 (pure black) to 100 (reference to white, which varies with the color and brightness of the illuminant); $a^{*}$ stands for the red-green contrast with red being positive, and green being negative; $b^{*}$ stands for; the blue-yellow contrast, with yellow being positive, and blue being negative (Polyzois et al., 1999; MacEvoy, 2003).

Measuring the $\mathrm{L}^{*} \mathrm{a} * \mathrm{~b} *$ values allows for the color difference, $\Delta \mathrm{E}$, between the objects being evaluated to be determined mathematically using the following formula: (Berns, 2000; MacEvoy, 2003).

$$
\Delta \mathrm{E}=\left[(\Delta \mathrm{L})^{2}+(\Delta \mathrm{a})^{2}+(\Delta \mathrm{b})^{2}\right]^{1 / 2}
$$

The average human can notice a $\Delta \mathrm{E}$ of five to six, and a trianed eye can detect a $\Delta \mathrm{E}$ of three to four (King \& deRijk, 2007). The human eye is very sensitive to changes in $\mathrm{a}^{*}$ and $\mathrm{b}^{*}$ when they approach zero, or away from the achromatic tones. A person can then notice a difference between two "shifted" grays with a $\Delta \mathrm{E}$ as small as 0.5 . If selecting tooth shades, the human can perceive a $\Delta \mathrm{E}$ equal to one (Kuehni \& Marcus, 1979). Another study noted that samples with color differences greater than two $\Delta \mathrm{E}$ units were correctly chosen by the observers $100 \%$ of the time (Seghi et al., 1989). King \& deRijk (2007) showed a study by Gross from 1979 on composites that a $\Delta \mathrm{E}$ between zero and two is imperceptible, a $\Delta \mathrm{E}$ between two and three as just perceptible, a $\Delta \mathrm{E}$ between three and eight as moderately perceptible, and a $\Delta \mathrm{E}$ greater than eight as markedly perceptible.

Johnston and Kao (1989) showed that evaluation of color by means of an extended rating scale for appearance match does not appear to allow any improved color description of dental materials, due to the numerous factors that affect color perception. Color measurement by a colorimeter gives a consistent color evaluation that may not be perceivable to human detection under controlled conditions. 


\section{CHAPTER 3. MATERIALS AND METHODS}

Three denture base liners were used in the present study: a silicone liner (Silk Line $^{\mathrm{TM}}$, J. Morita USA, Irvine, CA); a methyl methacrylate-free resin liner (GC Reline ${ }^{\mathrm{TM}}$, GC America, Inc., Alsip, IL); and a polyethyl methacrylate resin liner (Kooliner ${ }^{\mathrm{TM}}$, GC America, Inc., Alsip, IL). The materials and manufacturers are summarized in Table 3-1. Lucitone $199^{\circledR}$ (Dentsply, York, PA) disc samples were processed using a conventional compression heat-activated technique according to the manufacturer's recommendations. The samples were $20 \mathrm{~mm}$ in diameter, and $2 \mathrm{~mm}$ thick. After processing, the specimens were adjusted and polished to the original measurements of $20 \mathrm{~mm}$ by $2 \mathrm{~mm}$. A digital caliper was used to verify these measurements. The samples were stored in distilled water for 24 hours prior to adding the liners. All denture base samples were roughened and cleansed with alcohol before lining agents were applied at thickness of $2 \mathrm{~mm}$.

Silk Line required the placement of a primer onto the resin disc samples, which was allowed to air dry before liner application. The lining material was applied to the samples using a dispensing gun. Upon setting, a varnish was used to assist in sealing and smoothing the liner.

GC Reline required a bonding agent be applied to the denture base resin disc samples and allowed to air-dry for 10 seconds. After this, $1.8 \mathrm{~g}$ of powder and $1.0 \mathrm{~mL}$ of liquid were mixed and applied to the resin disc samples. Upon setting, the liner was polished in the same manner as a conventional acrylic denture base.

Kooliner required mixing $15 \mathrm{~mL}$ of powder and $6 \mathrm{~mL}$ of liquid for no more than 30 seconds. After mixing, the material was allowed to bench set for one to two minutes before application to the denture base resin disc samples. Upon setting, excess material was trimmed and smoothed using a hot spatula. After the addition of the liners to their respected resin disc samples, the samples were allowed to soak in distilled water for 24 hours at $23{ }^{\circ} \mathrm{C}$ before their initial baseline readings were recorded using a spectrocolorimeter (Labscan XE Spectrocolorimeter, Hunter Associates Laboratory, Reston, VA).

An equal number of samples from each liner group were assigned to one of three staining agents, including: cola (Coca-Cola Company, Atlanta, GA); grape juice (Welch, Billerica, MA); and coffee (Folger, Orrville, OH) (Table 3-2), and to one of three soaking solutions, including: two different effervescing cleaning agents (Efferdent, New Brunswick, NJ, and Polydent, Philadelphia, PA) and distilled water (Westover Dairy Inc., Lynchburg, VA) (Table 3-3). Distilled water acted as the control. The samples $(n=45)$ were further divided into nine subgroups of five for each liner material for testing purposes (Table 3-4).

Following a $12 \mathrm{hr}$. staining cycle at $23 \pm 2^{\circ} \mathrm{C}$, the samples were rinsed with distilled water, and then placed into the soaking solutions for a $12 \mathrm{hr}$ soaking cycle at $23 \pm$ $2^{\circ} \mathrm{C}$. All staining and soaking cycles were performed in a dark environment during the 
Table 3-1. Denture liner materials

\begin{tabular}{|c|c|c|c|c|}
\hline Material & Composition & $\begin{array}{l}\text { Method of } \\
\text { use }\end{array}$ & Code & $\begin{array}{c}\text { Manufac- } \\
\text { turer }\end{array}$ \\
\hline Silk Line & $\begin{array}{l}\text { Mixture of organic acids, zinc oxide, } \\
\text { strontiumglass, methacylates (paste); } \\
\text { solution of polyacylate in dichloromethane } \\
\text { (primer); mixture of polydimethyl } \\
\text { polymethylvinyl-siloxane, } \\
\text { polydimethylpolymethylhydrogen } \\
\text { siloxane and silica (varnish) }\end{array}$ & $\begin{array}{l}\text { Silicone- } \\
\text { chemically } \\
\text { activated }\end{array}$ & (L) & $\begin{array}{l}\text { J. Morita, } \\
\text { Irvine, CA }\end{array}$ \\
\hline $\begin{array}{c}\text { GC } \\
\text { Reline }\end{array}$ & $\begin{array}{c}\text { Butoxyethy Methacrylate, Benzyl } \\
\text { Methacrylate, 1,6 Hexanediol } \\
\text { Dimethacrylate, P-Tolyldiethanolamine, } \\
\text { Ethyl P-Dimethylaminobenzoate (liquid); } \\
\text { Polyethyl Methacrylate, Benzoyl } \\
\text { Peroxide, Silicone Dioxide (powder) }\end{array}$ & $\begin{array}{l}\text { PMMA- } \\
\text { chemically } \\
\text { activated }\end{array}$ & $(\mathrm{H})$ & $\begin{array}{l}\text { GC } \\
\text { America, } \\
\text { Alsip, IL }\end{array}$ \\
\hline Kooliner & $\begin{array}{l}\text { Isobutyl methacrylate, 2,4-Dihydroxy } \\
\text { benzophenone (liquid); } \\
\text { Polyethyl methacrylate, Benzoyl peroxide, } \\
\text { Silica, Crystalline-Quartz (powder) }\end{array}$ & $\begin{array}{l}\text { PMMA- } \\
\text { chemically } \\
\text { activated }\end{array}$ & $(\mathrm{K})$ & $\begin{array}{l}\text { GC } \\
\text { America, } \\
\text { Alsip, IL }\end{array}$ \\
\hline
\end{tabular}

Table 3-2. Staining substrates

\begin{tabular}{ccc}
\hline Solution & Code & Manufacturer \\
\hline Coffee & $(\mathrm{C})$ & $\begin{array}{c}\text { Folger } \\
\text { Orrville, OH }\end{array}$ \\
Cola & $(\mathrm{S})$ & $\begin{array}{c}\text { Coca-Cola } \\
\text { Atlanta, GA }\end{array}$ \\
Grape Juice & $(\mathrm{G})$ & Welch \\
& & Billerica, MA \\
\hline
\end{tabular}


Table 3-3. Denture soaking solutions

\begin{tabular}{|c|c|c|c|}
\hline Material & Composition & Code & Manufacturer \\
\hline Efferdent Plus & Tetrasodium EDTA & (E) & $\begin{array}{l}\text { Johnson \& Johnson } \\
\text { New Brunswick, NJ }\end{array}$ \\
\hline Polident Antibacterial & $\begin{array}{l}\text { Citric Acid, Sodium Carbonate, } \\
\text { Potassium Peroxymonosulfate, } \\
\text { Sodium Perborate Monohydrate }\end{array}$ & (P) & $\begin{array}{l}\text { GlaxoSmithKline } \\
\text { Philadelphia, PA }\end{array}$ \\
\hline Kroger Distilled Water & $\mathrm{H}_{2} \mathrm{O}$ & (W) & $\begin{array}{l}\text { Westover Dairy Inc } \\
\text { Lynchburg, VA }\end{array}$ \\
\hline
\end{tabular}

Table 3-4. Denture liners subdivided into sample groups labeled 1-45 for each staining solution and soaking solution used on that material

\begin{tabular}{ccc}
\hline Sample numbers & Staining agent & Cleansing agent \\
\hline $1-5$ & Coffee & Efferdent Plus \\
$6-10$ & Coffee & Polident Bacterial \\
$11-15$ & Coffee & Distilled Water \\
$16-20$ & Cola & Efferdent Plus \\
$21-25$ & Cola & Polident Bacterial \\
$26-30$ & Cola & Distilled Water \\
$31-35$ & Grape Juice & Efferdent Plus \\
$36-40$ & Grape Juice & Polident Bacterial \\
$41-45$ & Grape Juice & Distilled Water \\
\hline
\end{tabular}


60 days to help simulate intraoral conditions. This stain-soak cycle was continuously repeated, changing the soaking and staining solutions every day.

Denture liner color measurements were performed on the $1^{\text {st }}, 15^{\text {th }}, 30^{\text {th }}, 45^{\text {th }}$, and $60^{\text {th }}$ day. The spectrocolorimeter was calibrated with white and black calibration plates before each of the colorimetric measurements were made, according to the manufacturer's instructions. The samples were washed under distilled water and air dried prior to each color measurement. The readings were recorded and entered into a log book for future evaluation. The color differences were evaluated at the end of the study using the CIE L*a*b* colorimetric system. The color change $(\Delta \mathrm{E})$ of each specimen was calculated as follows (Berns, 2000; MacEvoy, 2003):

$$
\Delta \mathrm{E}=\left[(\Delta \mathrm{L})^{2}+(\Delta \mathrm{a})^{2}+(\Delta \mathrm{b})^{2}\right]^{1 / 2}
$$

Where $\mathrm{a}^{*}$ and $\mathrm{b}^{*}$ are on the chromatic scale and represent: red corresponds as positive $\mathrm{a}^{*}$ and green as negative $a^{*}$; yellow corresponds to positive $b^{*}$ and blue to negative $b^{*}$; and $\mathrm{L}^{*}$ represents lightness and darkness on a scale of 0 to $100 . \Delta \mathrm{L}^{*}, \Delta \mathrm{a}^{*}$, and $\Delta \mathrm{b}^{*}$ represent the differences measured in $\mathrm{L}^{*}, \mathrm{a}^{*}$, and $\mathrm{b}^{*}$ values between the baseline measurements, and those measured after immersion for different time intervals (Polyzois et al., 1999; MacEvoy, 2003).

Mean and standard deviations were calculated for changes in color statistics $\left(\Delta \mathrm{a}^{*}\right.$, $\Delta \mathrm{b}^{*}, \Delta \mathrm{L}^{*}, \Delta \mathrm{E}^{*}$ ) at all time points. Three-way analyses of variance (ANOVA) were performed to determine whether there were statistically significant differences in color change among materials, cleansers, and staining agents, and to test for interaction effects among the three experimental factors.

Statistical Package for the Social Sciences for Windows Release 18 (SPSS IBM, Inc, Chicago, IL) was used for all statistical analyses. A $p$ value of $p<.05$ was considered to be statistically significant. $95 \%$ confidence levels for means were also calculated. 


\section{CHAPTER 4. RESULTS}

The mean baseline color measurements $\left(\mathrm{L}^{*}, \mathrm{a}^{*}\right.$, and $\left.\mathrm{b}^{*}\right)$ for the three denture liners are presented in Table 4-1. Before the specimens were immersed into each solution, $\mathrm{L}^{*}$ values were positive (whiter), $\mathrm{a}^{*}$ values were positive (redder), and $\mathrm{b}^{*}$ values were positive (yellower). Color changes $(\Delta \mathrm{E})$ over the 60 days of the study are presented in Figure 4-1 and Table 4-2. Figure 4-1 shows that most color change occurred before the $15^{\text {th }}$ day, with a $\Delta \mathrm{E}$ greater than 12.0 for all materials involved. From day 15 until day 60 very little difference was noted among the samples.

A three-way analysis of variance (ANOVA) was used to test differences among the three liner types (Kooliner, Silk Line, GC Reline), three staining agents (coffee, cola, grape juice), and three soaking solutions (distilled water, Efferdent, Polydent). The dependent variable of the ANOVA test was overall color change $(\Delta \mathrm{E})$ from baseline to day 60. Primary results of ANOVA $(\Delta \mathrm{E})$ at 15 and 60 days show at 15 days there were statistically significant main effects for soaking agent, liner type, and stain type, indicating differences across categories of those experimental factors $(p<0.05)$. Figures 4-2, 4-3, and 4-4 show the main effects of soaking solutions, stain type, and liner type. The color differences at 15 days are shown on the left portion of each figure with each having a mean $\Delta \mathrm{E}$ greater than 13 from baseline readings.

At 60 days, there were statistically significant main effects for soaking agents, stain type, and liner type, indicating differences across categories of those experimental factors. Distilled water had a greater $\Delta \mathrm{E}$ as compared to the two cleansers, grape juice showed the greatest $\Delta \mathrm{E}$ when compared to cola and coffee, and Silk Line's $\Delta \mathrm{E}$ was greater than the two other liners examined. Table 4-3 shows the ANOVA results from the study. None of the interaction effects were statistically significant, which means that the effects of each experimental factor (soaking agent, stain, liner) were consistent, regardless of the other experimental factors.

When viewing Figures 4-2, 4-3, and 4-4 at 60 days a marked change in mean $\Delta \mathrm{E}$ can be seen, specifically when viewing distilled water, coffee and grape juice, and Silk Line as compared to baseline readings. Between days 15 and 60 only distilled water and Silk Line showed statistically significant change. 
Table 4-1. Mean and standard deviation (SD) of baseline cielab color measurements of each denture liner before treatment

\begin{tabular}{ccrrr}
\hline Liner & Mean/SD & $\mathbf{L}^{*}$ & $\mathbf{a}^{*}$ & $\mathbf{b}^{*}$ \\
\hline Kooliner & Mean & 58.21 & 23.08 & 15.37 \\
& SD & 1.75 & 1.38 & 1.36 \\
Silk Line & Mean & 51.53 & 18.73 & 9.91 \\
& SD & 0.58 & 0.66 & 0.51 \\
GC Reline & & & & \\
& Mean & 47.44 & 19.31 & 10.00 \\
& SD & 1.77 & 1.18 & 0.70 \\
\hline
\end{tabular}



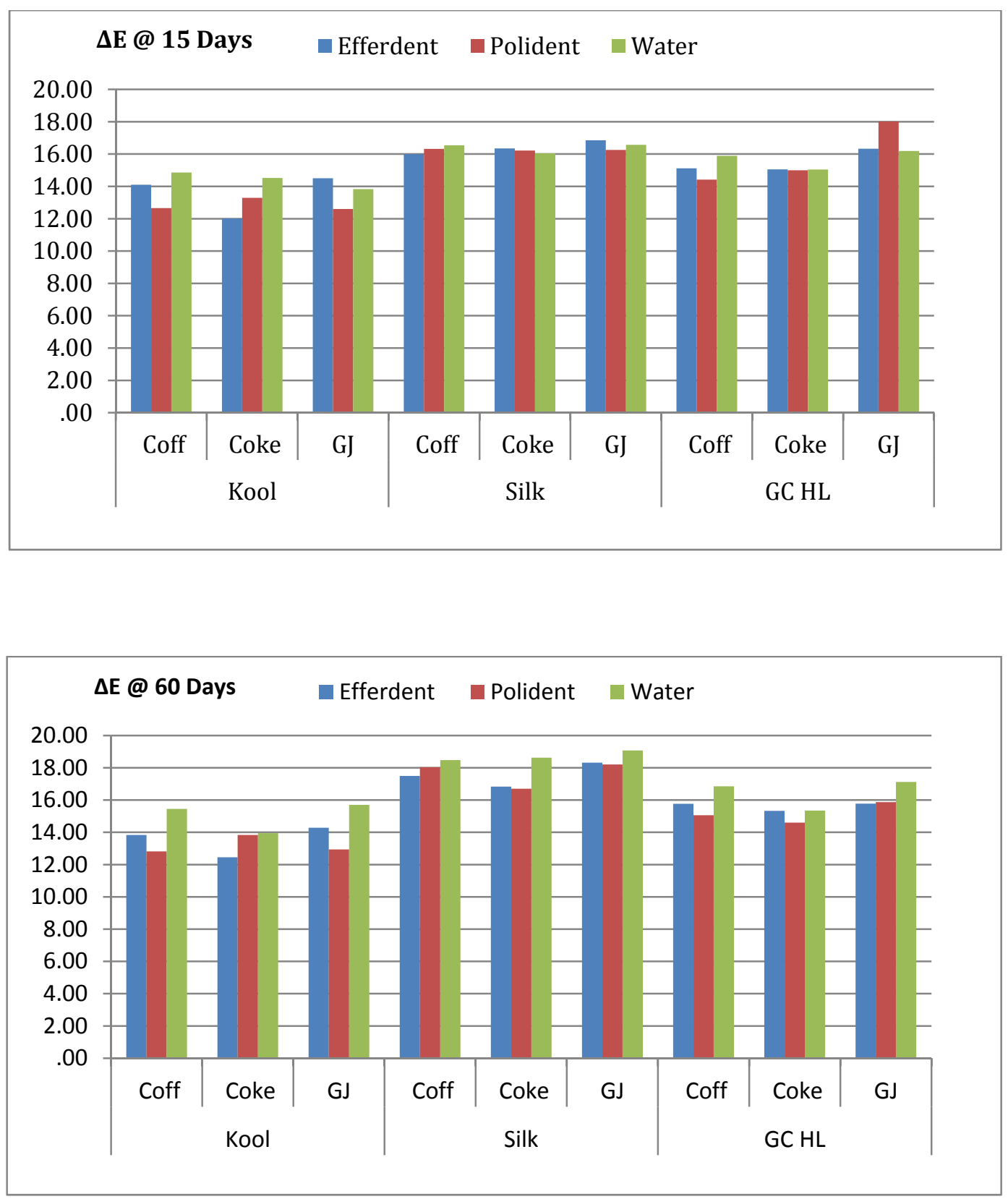

Figure 4-1. Mean color changes $(\Delta E)$ of denture liners, stain agents, and soaking agents at first reading (15 days) until the end of the study (60 days) 
Table 4-2. Mean color changes $(\Delta E)$ of denture liners, stain agent, and cleanser over the time of the study of 60 days

\begin{tabular}{|c|c|c|c|c|c|c|c|c|c|c|}
\hline \multirow[b]{3}{*}{ Resin } & \multirow[b]{3}{*}{$\begin{array}{l}\text { Stain } \\
\text { agent }\end{array}$} & \multirow[b]{3}{*}{ Cleanser } & \multicolumn{8}{|c|}{ Color change $(\Delta E)$ from baseline measurements } \\
\hline & & & \multicolumn{2}{|c|}{ Day 15} & \multicolumn{2}{|c|}{ Day 30} & \multicolumn{2}{|c|}{ Day 45} & \multicolumn{2}{|c|}{ Day 60} \\
\hline & & & $\mathbf{M}$ & SD & $\mathbf{M}$ & SD & $\mathbf{M}$ & SD & $\mathbf{M}$ & SD \\
\hline \multirow[t]{9}{*}{ Kooliner } & \multirow[t]{3}{*}{ Coffee } & Efferdent & 14.10 & 1.04 & 14.07 & 1.19 & 13.70 & 0.98 & 13.83 & 1.95 \\
\hline & & Polident & 12.66 & 0.63 & 13.50 & 0.74 & 12.68 & 0.56 & 12.82 & 1.14 \\
\hline & & Water & 14.86 & 0.98 & 13.40 & 1.24 & 14.75 & 1.01 & 15.45 & 0.82 \\
\hline & \multirow[t]{3}{*}{ Coke } & Efferdent & 12.01 & 0.76 & 11.27 & 0.91 & 11.31 & 1.06 & 12.45 & 0.98 \\
\hline & & Polident & 13.29 & 1.34 & 13.54 & 1.94 & 13.76 & 1.06 & 13.84 & 1.57 \\
\hline & & Water & 14.52 & 1.65 & 14.38 & 2.87 & 14.30 & 1.81 & 13.95 & 2.15 \\
\hline & \multirow[t]{3}{*}{$\begin{array}{l}\text { G. } \\
\text { Juice }\end{array}$} & Efferdent & 14.50 & 0.36 & 13.80 & 1.82 & 14.80 & 1.79 & 14.29 & 0.54 \\
\hline & & Polident & 12.60 & 0.82 & 12.25 & 1.01 & 18.35 & 5.60 & 12.94 & 1.54 \\
\hline & & Water & 13.83 & 0.56 & 13.82 & 0.98 & 14.76 & 1.41 & 15.70 & 2.08 \\
\hline \multirow[t]{8}{*}{ Silk Line } & \multirow[t]{3}{*}{ Coffee } & Efferdent & 15.99 & 1.01 & 16.69 & 0.55 & 17.16 & 1.78 & 17.49 & 1.49 \\
\hline & & Polident & 16.32 & 1.35 & 16.83 & 1.58 & 17.59 & 1.65 & 18.04 & 1.75 \\
\hline & & Water & 16.54 & 1.57 & 17.20 & 0.75 & 18.22 & 1.34 & 18.48 & 1.91 \\
\hline & \multirow[t]{3}{*}{ Coke } & Efferdent & 16.35 & 0.93 & 16.43 & 1.59 & 16.66 & 1.73 & 16.83 & 1.01 \\
\hline & & Polident & 16.22 & 0.49 & 16.20 & 1.60 & 16.74 & 1.76 & 16.70 & 0.82 \\
\hline & & Water & 16.05 & 1.78 & 17.33 & 1.71 & 18.16 & 1.35 & 18.63 & 0.65 \\
\hline & \multirow{2}{*}{$\begin{array}{c}\text { G. } \\
\text { Juice }\end{array}$} & Efferdent & 16.85 & 0.64 & 17.41 & 0.67 & 17.86 & 0.78 & 18.32 & 1.34 \\
\hline & & Polident & 16.25 & 1.07 & 17.09 & 0.59 & 18.12 & 1.32 & 18.20 & 1.65 \\
\hline \multirow{9}{*}{$\begin{array}{c}\text { GC } \\
\text { Reline }\end{array}$} & \multirow[t]{3}{*}{ Coffee } & Efferdent & 15.12 & 0.97 & 16.06 & 0.89 & 16.20 & 0.82 & 15.77 & 0.84 \\
\hline & & Polident & 14.42 & 0.54 & 14.90 & 1.02 & 15.10 & 0.93 & 15.06 & 0.51 \\
\hline & & Water & 15.89 & 0.23 & 16.47 & 1.10 & 16.65 & 0.67 & 16.86 & 0.92 \\
\hline & \multirow[t]{3}{*}{ Coke } & Efferdent & 15.05 & 0.87 & 14.87 & 0.93 & 14.81 & 0.54 & 15.33 & 0.78 \\
\hline & & Polident & 15.00 & 0.65 & 14.50 & 0.27 & 14.96 & 0.24 & 14.60 & 0.65 \\
\hline & & Water & 15.04 & 0.59 & 15.52 & 0.81 & 15.60 & 0.89 & 15.35 & 0.86 \\
\hline & \multirow[t]{3}{*}{$\begin{array}{c}\text { G. } \\
\text { Juice }\end{array}$} & Efferdent & 16.33 & 0.32 & 15.54 & 0.30 & 15.44 & 1.14 & 15.78 & 0.47 \\
\hline & & Polident & 18.01 & 0.54 & 16.03 & 0.58 & 16.96 & 1.25 & 15.87 & 0.28 \\
\hline & & Water & 16.19 & 0.30 & 16.02 & 0.46 & 15.83 & 1.23 & 17.12 & 0.94 \\
\hline
\end{tabular}




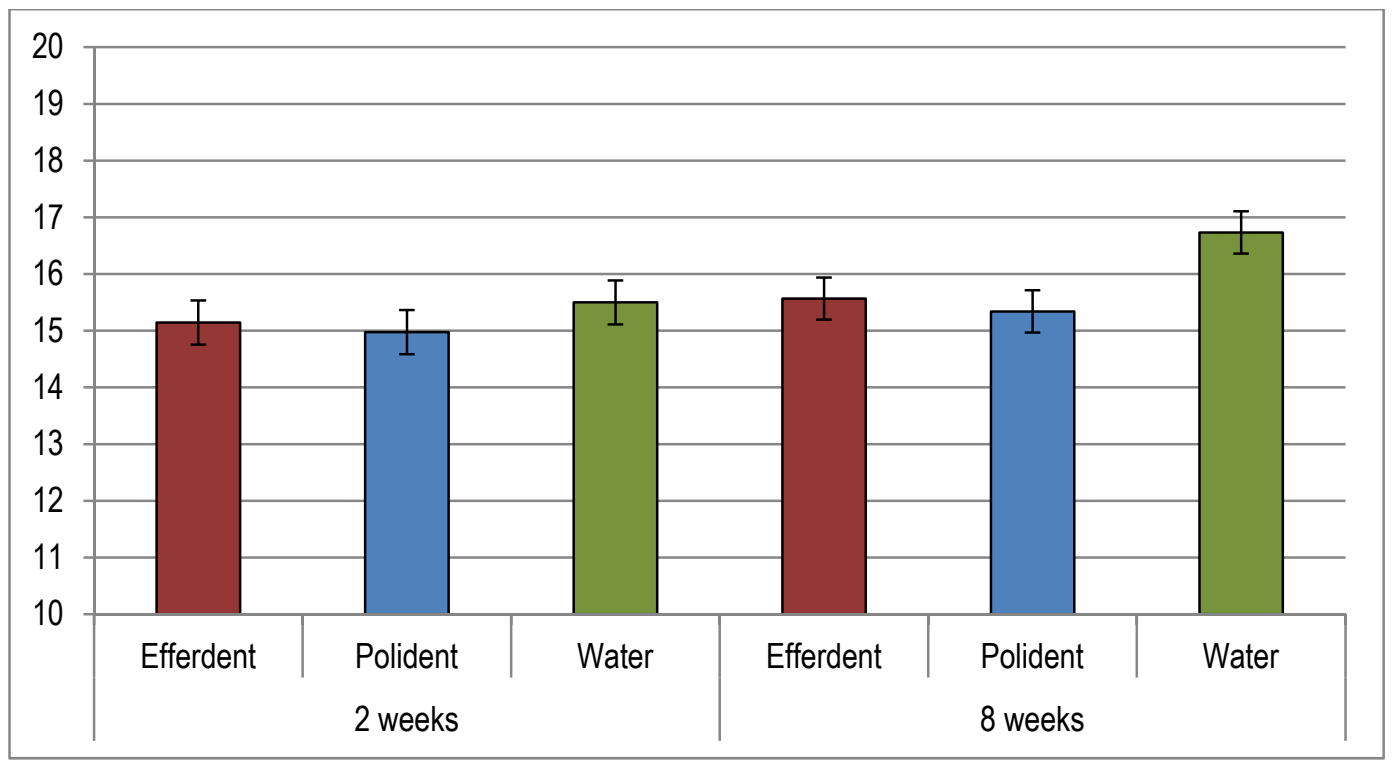

Figure 4-2. Mean color change $(\Delta E)$ at 15 and 60 days with $95 \%$ confidence intervals by soaking agent type

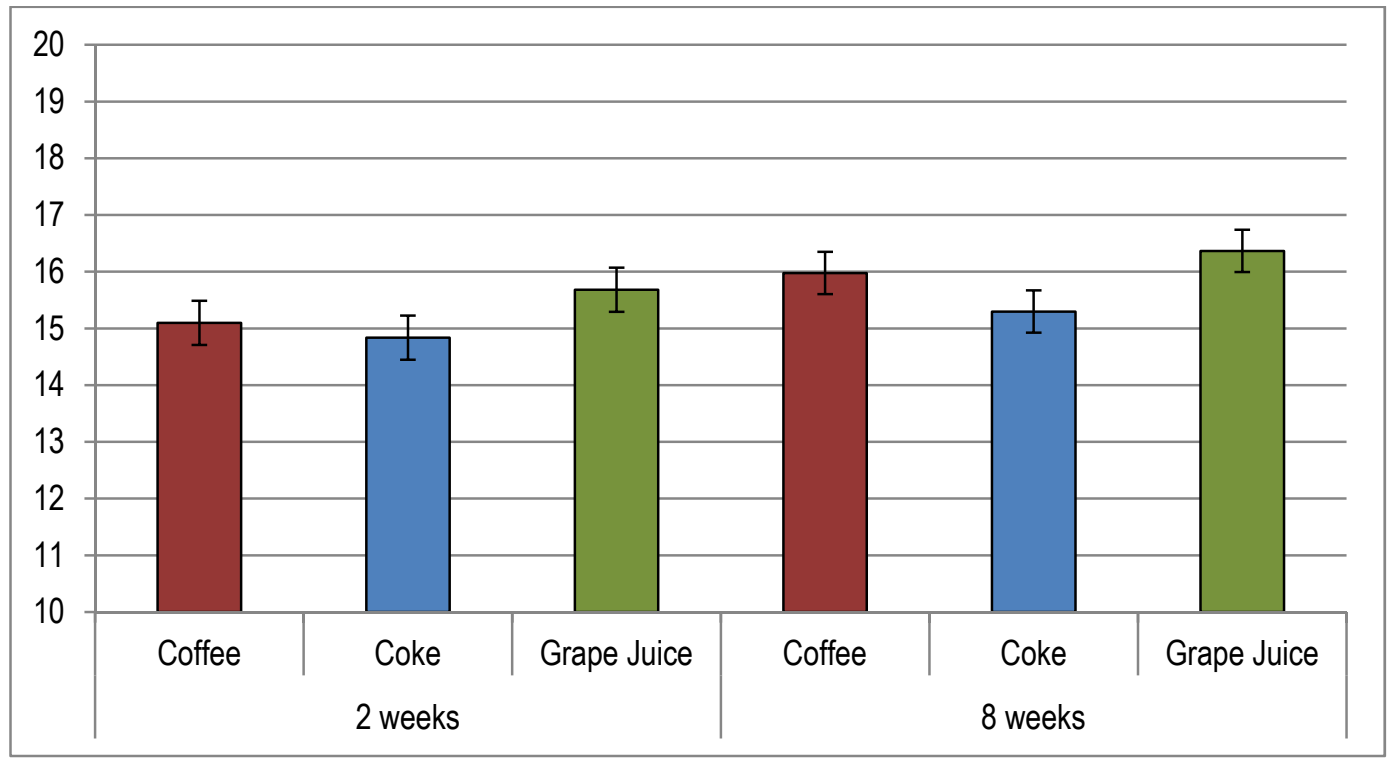

Figure 4-3. Mean color change $(\Delta E)$ at 15 and 60 days with $95 \%$ confidence intervals by stain type 


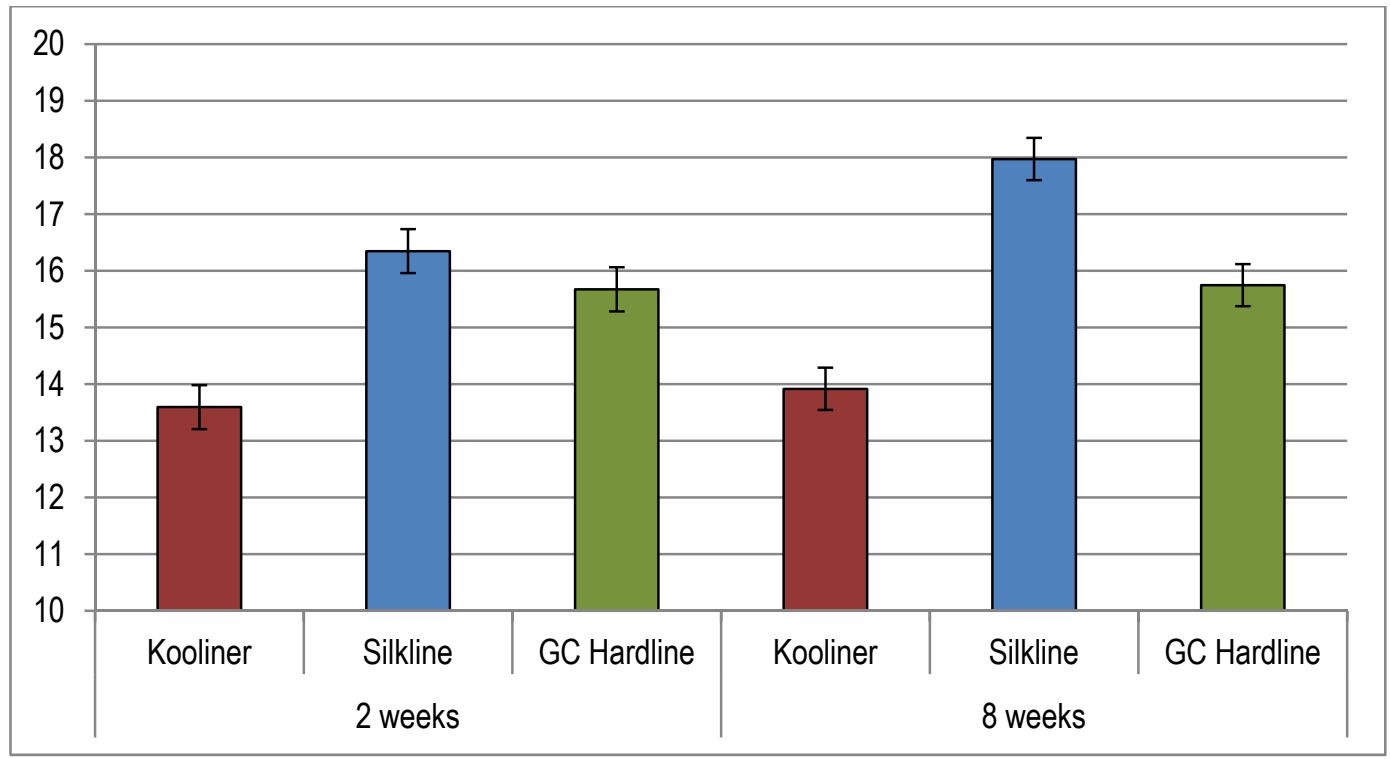

Figure 4-4. Mean color change $(\Delta E)$ at 15 and 60 days with $95 \%$ confidence intervals by liner type 
Table 4-3. Three-way ANOVA table for mean color change $(\Delta E)$ from baseline measurements and at 60 days into the study

\begin{tabular}{clllll}
\hline Source & $\begin{array}{c}\text { Sum of } \\
\text { squares }\end{array}$ & $\boldsymbol{d f}$ & $\begin{array}{c}\text { Mean } \\
\text { square }\end{array}$ & $\boldsymbol{F}$ & Sig \\
\hline Model & 34515.080 & 27 & 1278.336 & 803.142 & .000 \\
Denture Liner & 34412.915 & 3 & 11470.972 & 7206.881 & .000 \\
Stain Agent & 26.312 & 2 & 13.156 & 8.266 & .000 \\
Cleanser & 50.192 & 2 & 25.096 & 15.767 & .000 \\
Denture Liner * Stain Agent & .488 & 4 & .122 & .077 & .989 \\
Denture Liner * Cleanser & 3.592 & 4 & .898 & .564 & .689 \\
Stain Agent * Cleanser & 2.881 & 4 & .720 & .453 & .770 \\
Denture Liner * Stain Agent & & & & & \\
$*$ Cleanser & 18.699 & 8 & 2.337 & 1.469 & .177 \\
Error & 171.900 & 108 & 1.592 & & \\
Total & 34686.980 & 135 & & & \\
\hline
\end{tabular}




\section{CHAPTER 5. DISCUSSION}

The color change of a dental prosthesis can be one of the determining factors of patient's acceptance of the prosthesis, regardless if it is a denture or porcelain crown (Hong et al., 2009). Other studies have stated that color changes among acrylic resins and liners will continue to occur over time regardless of the staining agent used (Shotwell et al., 1992; Sarac et al., 2007; Hong et al., 2009; Goiato et al., 2011). However, in my study little to no color change was noted from days 15 to 60 . These findings suggest that the amount of stain that infiltrated the liners from baseline to 15 days was so dramatic, that the liners had potentially reached their thresholds for incorporation of stain.

The present study examined color changes in three liners, two acrylic-based liners and one silicone-based liner, using three different common causes of staining to represent everyday use. These liners were soaked with common denture cleansers according to the manufacturer's recommendations. The color changes were evaluated using the CIE L*a*b* colormetric system (Central de la CIE, 2004).

Studies have examined methods for the assessment of color differences among various denture products. One study showed that $50 \%$ of all observers could detect a color difference of $1.9 \Delta \mathrm{E}$ units with a $95 \%$ confidence interval (Alghazali et al., 2012). In this same study they noted that a color difference of $4.2 \Delta \mathrm{E}$ units was perceived as unacceptable in $50 \%$ of observers, and recommended that this color difference should be addressed (Alghazali et al., 2012). Ghinea showed a 50\% acceptability threshold for dental ceramics was $3.46 \Delta \mathrm{E}$ units, with the $50 \%$ perceptibility threshold being $1.8 \Delta \mathrm{E}$ units. These thresholds, acceptability and perceptibility, were determined by having observers examine ceramic disc pairs and asked two questions: 1) "Would you accept the color difference between the two ceramic discs under clinical conditions?" 2) "Can you detect a color difference between the two ceramic discs?" (Ghinea et al., 2010).

By examining the $L^{*}, a^{*}, b^{*}$ of each sample, it was noted each CIE $L^{*} a^{*} b^{*}$ variable decreased. $L^{*}$ values went from around 50 to near zero and $\left(a^{*}, b^{*}\right)$ values went from positive to negative during the initial 15 days of the study. Calculating $\Delta \mathrm{E}$ 's at the 15 day reading, it was concluded that significant color change was noted $(\Delta \mathrm{E}>12.0)$ in all of the liners being tested, regardless of the staining and soaking agent combination. From days 15 to 60 the average $\Delta \mathrm{E}$ was 0.67 among all liners, stains, and soaking agents combined. This mean $\Delta \mathrm{E}$ was slightly skewed due to the higher color changes noted in Silk Line. Silk Line's mean $\Delta \mathrm{E}$ was 1.48 , as compared to Kooliner and GC Reline, with mean $\Delta \mathrm{E}$ 's of 0.30 and 0.08 during the same time period. Based on previous studies examining dental restorative materials, a $\Delta \mathrm{E}$ ranging from 2.72 to 4.2 was considered clinically unacceptable $50 \%$ of the time by observers involved in the respective studies (Ruyter et al., 1989; Hong et al., 2009 Ghinea et al., 2010; Alghazali et al., 2012).

The silicone liner examined in this study (Silk Line) showed a greater overall change in color compared to the two acrylic resin-based liners (Kooliner and GC Reline). Other studies have shown that silicones appeared to be more resistant to stain when 
compared to acrylic-based liners (Jin et al., 2003; Oguz et al., 2007; Sarac et al., 2007; Leite et al., 2010). The difference in these studies was the silicone liners were being compared to soft acrylic resin-based liners, which contain plasticizers. Plasticizers act as lubricants for the polymer chains which make it easier for the chains to slide over one another. This action helps to keep the liner material softer for longer periods of time, but eventually the plasticizers leach out and the material hardens. This continued leaching of material can lead to incorporation of color into the liner by oxidation of the reacted carbon-carbon double bonds that produce colored peroxide compounds (Anil et al., 1999; Oliveira et al., 2006; Ergun \& Nagas, 2007). The two acrylic resin-based liners in the current study are considered hardliners, and do not contain these plasticizers.

When examining the main effects of stains effects, the results showed a dramatic color change over the 60 day study. Grape juice showed the greatest color change upon the liners, while cola had the least effect on overall color change. Causative factors that can contribute to color changes in the liners can include, stain accumulation, water sorption, poor bonding, surface roughness, and chemical degradation (Anil et al., 1999). However, the mechanism of color change in this study cannot be known exactly. When view the effects that the soaking agents had on the liners, the results showed that all agents had little effect on preventing the initiation of color change. Efferdent and Polydent did show less overall color change, as compared to distilled water. Studies examining the effects of cleansers on liners have shown that the cleansers can cause bleaching of the liners (Goll et al., 1983; Sultana, 1991). Reasons for the results that we obtained in the current study can only be speculated without further investigation into the mechanical and chemical properties of the liners.

Results of this study suggest that exposure of the denture liners to stains will alter the color of the liners regardless of the denture soaking agent used. Furthermore, color change initiated in the denture liners appeared to stabilize over time. My results seem to support the hypotheses involved in the study as: 1) All liners did change color when subjected to repetitive stain/cleanser cycles. 2) The liners did continue to change color over the course of the study, although not statistically significant after the initial 15 days. 3) The cleansers did appear to have a positive influence on the overall color change of the liners when compared to water. 


\section{CHAPTER 6. CONCLUSIONS}

The results of the study suggest the following:

1. Exposing denture liners investigated to the staining agents used resulted in clinically discernible color change.

2. Use of denture cleansers had little beneficial effect on liner discoloration as compared to immersion in water.

3. Following initial liner color change at two weeks, little to no further color change was noted regardless of staining agent or soaking fluid.

4. The silicone liner demonstrated the greatest color change when compared to the resin liners.

5. Conventional denture cleansers were statistically similar $(p>0.05)$ to water with respect to the improvement of discolorations evaluated in this study. 


\section{CHAPTER 7. LIMITATIONS AND FUTURE APPLICATIONS}

The limitations of this in vitro study include:

1. Soaking liner samples in staining solutions for 12 hours consecutively does not represent natural occurrences in human behavior.

2. The three staining agents tested are not the only materials that can potentially affect color change.

3. Gathering of baseline color change measurements should have been initiated earlier in the study, rather than in two-week intervals.

4. Water should have been included as a staining agent for accurate analysis of cleanser effects on the liners.

Future applications for this in vitro study:

1. Additional investigation upon other factors of stains and soaking agents upon the materials tested-i.e. solubility, resiliency, and adhesion.

2. Testing denture liners using patient logs of substances eaten and drank during a specified time period when using specific soaking agents.

3. Having a baseline sample that is unaffected by outside influences when seeking the information being examined. 


\section{LIST OF REFERENCES}

Albrektsson, T., Zarb, G.A. The Branemark ossointegrated implant. Chicago:

Quintessence Pub. Co., Inc., ,1989:167.

Alghazali, N. et al. Assessment of perceptibility and acceptability of colour difference of denture teeth. Journal of Dentistry 2012, http://dx.doi.org/10.1016/j.dent.2012.04.023.

Anil, N., Hekimoglu, C., Sahin, S. Color stability of heat-polymerized and autopolymerized soft denture liners. J Prosthet Dent. 1999;81:481-484.

Anusavice, K. J. Phillips' Science of Dental Materials (11th ed),St Louis, MO: Elsevier Science (USA), 2003: 143-166 \& 721-756.

Barnhart, G.W. Properties and procedures of silicone for soft denture bases. J Dent Res. 1964;4:118-120.

Bates, J.F., Smith, D.C. Evaluation of indirect resilient liners for dentures: laboratory and clinical tests. JADA. 1965;70:344-353.

Berns, R.S. Billmeyer and Saltzman's principles of color technology ( $3^{\text {rd }}$ ed.). New York: Wiley, 2000: 72.

Braden, M. Tissue conditions: 1. Composition and structure. J Dent Res. 1970;49:145148.

Brauer, G. Dental applications of polymers: a review. JADA. 1966;72:1151-1158.

Brown, D. Resilient soft liners and tissue conditioners. Br Dent J. 1988;164:357-360.

Buchsbaum, G., Bloch, O. Color categories revealed by non-negative matrix factorization of Munsell color spectra. Vision Research. 2002;42:559-563.

Burns, D.R., Burns, D.A., DiPietro, G.J., Gregory, R.L. Response of processed resilient denture liners to candida albicans. J Prosthet Dent. 1987;57:507-512.

Christensen, G.J. Relining, rebasing partial and complete dentures. J Am Dent Assoc. 1995;126(4):503-506.

CIE (Commission Internationale de L'Eclairage). Colorimetry - technical report. CIE Pub. No. 15 ( $3^{\text {rd }}$ ed.), Vienna: Bureau Central de la CIE, 2004:16-20.

Craig, R.G., Gibbons, P. Properties of resilient denture liners. J Amer Dent Assoc., 1961;63:382-390. 
De Almeida, E.O., Filho, H.G., Goiatto, M.C. The use of transitional implants to support provisional prostheses during the healing phase: a literature review. Quintessence Int. 2011; Jan;42(1):19-24.

Dhir, G., Berzins, D.W., Dhuru, V.B., Periathamby, A.R., Dentino, A. Physical properties of denture base resins potentially resistant to Candida adhesion. J Prosthodont 2007;16:465-472.

Dogan, O.M., Keskin, S., Dogan, A., Ataman, H., Usanmaz, A. Structure-property relation of a soft liner material used in denture applications. Dent Mater. 2006;26:329334.

Dootz, E.R., Koran, A., Craig, R.G. Comparison of the physical properties of 11 soft denture liners. J Prosthet Dent. 1992;67(5): 707-712.

Ergun, G., Nagas, I.C. Color stability of silicone or acrylic denture liners: an in vitro investigation. Eur J Dent. 2007;1:144-151.

Ergun, G., Nagas, I.C. In vitro color stability of soft denture liners after accelerated aging. Cilt. 2007;31:65-73.

Garcia, L.T., Jones, J.D. Soft liners. Dent Clin N Am. 2004;48:709-720.

Ghinea, R., Perez, M.M., Herrera, L.J., Rivas, M.J., Yerba, A., Paravina, RD. Color difference thresholds in dental ceramic. Journal of Dentistry 2010;38:57-64.

Goiato, M.C., Zuccolotti, B., Moreno, A., dos Santos, D.M., Pesqueira, A.A., Dekon, S. Color change of soft denture liners after storage in coffee and coke. Gerodont. 2011;28:140-145.

Goll, G., Smith, D., Plein, Joy B. The effect of denture cleansers on temporary soft liners. J Prosthet Dent., 1983;50:466-472.

Hayakawa, I., Hirano, S., Takahashi, Y., et al. Changes in the masticatory function of complete denture wearers after relining the mandibular denture with a soft denture liner. Int J Prosthodont. 2000;13(3):227-231.

Hayakawa, I., Kawae, M., Tsuji, Y., Mashuhara, E. Fluoroethyline copolymer and its clinical evaluation. J Prosthet Dent. 1984;51:310-313.

Hill, E.E., Rubel, B. Direct chairside hard reline at delivery of a newly fabricated distal extension removable partial denture: considerations and techniques. J Can Dent Assoc. 2011;77:b84. 
Hong, G., Murata, H., Li, Y., Sadamori, S., Hamada, T. Influence of denture cleansers on the color stability of three types of denture base acrylic resin. J Prosthet Dent 2009;101:205-213.

International Organization for Standardization. ISO/FDIS. 10139-1. Dentistry-resilient lining materials for removable dentures-part 1: short-term materials $\left(1^{\text {st }}\right.$ ed. $)$. December 1 , 1991.

International Organization for Standardization. ISO/FDIS 10139-2. Dentistry-soft lining materials for removable dentures-part 2: materials for long-term use. 10139-2:1999(E).

Jin, C., Nikawa, H., Makihira, S., Hamada, T., Furukawa, M., Murata, H. Changes in surface roughness and colour stability of soft denture lining materials caused by denture cleansers. J Oral Rehab. 2003;30:125-130.

Johnston, W.M., Kao, E.C. Assesment of appearance match by visual observation and clinical colorimetry. J Dent Res. 1989;68:819-822.

Jones, D.W., Sutow, E.J., Graham, B.S., Milne, E.J. Clinical implication of resilient denture lining material research part 1: flexibility and elasticity. J Prosthet Dent. $1989 ; 62: 421-428$.

Jorge, J.H., Giampaolo, E.T., Vergani, C.E., Machado, A.L., Pavarina, A.C., Carlos, I.Z. Biocompatibility of denture base acrylic resins evaluated in130culture of L929 cells. Effect of polymerisation cycle and post-polymerisation treatments. Gerodontology. 2007;24:52-57.

Kawano, F., Dootz, E.R., Koran, A., Craig, R.G. Sorption and solubility of 12 soft denture liners. J Prosthet Dent. 1994;72(4):393-398.

Kawano, F., Ohguri, T., Koran III, A., et al. Influence of lining design of the processed soft denture liners on cushioning effect. J Oral Rehab. 1999;26(12):962-968.

Khindria, S.K., Mittal, S., Sukhija, U. Evolution of denture base materials. J Indian ProsthodontSoc, 2009:9;64-69.

Kim, J., Lee, J.S., Chang, J., Millstein, P., Wright, R.F. A method for adapting existing removable complete dentures to immediate implants. J Mass Dent Soc. 2011;60:36-37.

King, K.A., deRijk, W.G. Variations of L*a*b* values among Vitapan classical shade guides. J Prosthodont. 2007;16:352-356.

Klinment, K., Stol, M., Raab, M., Stoker, J. Study on a new soft denture liner of the softdent type. J Biomed Mater Res. 1968;2:473-487. 
Kuehni, R.G., Marcus, R.T. An experiment in visual scaling of small color differences. Color Res Appl. 1979;4:83-91

Lai, Y., Lui, H., Lee, S. In vitro color stability, stain resistance, and water sorption of four removable gingival flange materials. J Prosthet Dent. 2003;90:293-300.

Lammie, G.A., Storer, R. A preliminary report on resilient denture plastics. J Prosthet Dent. 1958;8:450-464.

Leggat, P.A. \& Kedjarune, U. Toxicity of methyl methacrylate in dentistry. Int Dent J. 2003;53:126-131.

Leite, V., Pisani, M.X., Paranhos, H., Souza, R.F., Silva-Lovato, C.H. Effect of ageing and immersion in different beverages on properties of denture lining materials. J Appl Oral Sci. 2010;18:372-378.

Lung, C.Y. \& Darvell, B.W. Minimization of the inevitable residual monomer in denture base acrylic. Dent Mater. 2005;21:1119-1128.

MacEvoy B: Color model and color wheels. Hand- print, 2005. www.handprint.com/HP/WCL/color6.html. Accessed on 5 March 2012.

McCabe, J.F. Soft lining materials: composition and structure. J Oral Rehabil. 1976;3:273-278.

Munksgaard, E.C. Leaching of plasticizers from temporary denture soft lining materials. Eur J Oral Sci. 2004:112;101-104.

Munsell, A.H. A pigment color system and notation. Amer Jof Psych, 1912;23:236-244.

Murray, M.D. \& Darvell, B.W. The evolution of the complete denture base. Theories of complete denture retention--a review. Part 1. Aust Dent J 1993;38:216-219.

Nickerson, D. History of the Munsell color system, company, and foundation. Color Research and Application, 1976;1:7-10.

Nikawa, H., Iwanaga, H., Hamada, T., Yuhta, S. Effects of denture cleansers on direct soft denture materials. J Prosthet Dent. 1994;72:657-662.

Oguz, S., Mutluay, M.M., Dogan, O.M., Bek, B. Color change evaluation of denture soft lining materials in coffee and tea. Dent Mater. 2007;26:209-216.

Oliveira, L.V., Mesquita, M.F., Henriques, G., Consani, R., Fragoso, W.S. The compatibility of denture cleansers and resilient liners. J Appl Oral Sci. 2006;14:286-290. 
Parr, G.R., Rueggeberg, F.A., In vitro hardness, water sorption, and resin solubility of laboratory-processed and autopolymerized long-term resilient denture liners over one year of water storage. J Prosthet Dent. 2002;88:139-144.

Patrick, D.G., van Noort, R., Found, M.S. The influence of heat treatment on the impact performance of sports mouthguard materials Composites Part A: Applied Sci and Mfg 2006;37:1423-1427.

Peyton, F.A. History of resins in dentistry. Dent Clin North Am. 1975;19:211-22.

Phoenix, R.D. Denture base materials. Dent Clin North Am. 1996;40:113-120.

Phoenix, R.D. \& Fleigel, J.D. Cast modification for immediate complete dentures: traditional and contemporary considerations with an introduction of spatial modeling. J Prosthet Dent. 2008;100:399-405.

Polyzois, G.L., Yannikakis, S.A., Zissis, A.J. Color stability of visible-light cured, hard direct denture reliners: an in vitro investigation. Int J Prosthodont. 1999;12:140-146.

Qudah, S., Harrison, A., Huggett, R. Soft lining materials in prosthetic dentistry: a review. Int J Prosthodont. 1990;3(5):477-483.

Robinson, J.E. Clinical experiments and experiences with silicone rubber in dental prosthetics. J Prosthet Dent, 1963;13:669-675.

Rueggeberg, F.A. From vulcanite to vinyl, a history of resins in restorative dentistry. J Prosthet Dent. 2002;87:364-379.

Ruyter, I.E., Nilner, K., Moller, B. Color stability of dental composite resin materials for crown and bridge veneers. Dental Materials 1987;3:246-251.

Sarac, D., Sarac, Y.S., Kurt, M., Yuzbasioglu, E. The effectiveness of denture cleansers on soft denture liners colored by food colorant solutions. J Prosthodont. 2007;16:185191.

Sarka, R.J. Complete dentures: are they out of phase with current therapy? Compendeium 1996;17:94-96.

Schmidt, W.F., Smith, D.E. A six-year retrospective study of molloplast-B lined dentures. Part II: liner serviceability. J Prosthet Dent. 1983;50:459-465.

Seghi, R.R., Hewlett, E.R., Kim, J. Visual and instrumental colorimetric assessments of small color differences on translucent dental porcelain. J Dent Res. 1989;68:1760-1764.

Shotwell, J.L., Razzoog, M.E., Koran, A. Color stability of long-term soft denture liners. J Prosthet Dent. 1992;68:836-838. 
Sultana, A. Resilient liners for removable dentures. Master's Thesis, University of Sydney, Australia, 1991: 4-18, 38-42, 67-68.

Sweeney, W.T. Denture base materials, and what to expect of them. J Am Dent Assoc. 1938;23:243-52.

Thomas, C.J., Nutt, J. The in-vitro fungicidal properties of visco-gel alone and combined with nystatin and amphotericin B. J Oral Rehabil. 1978;5:167-172.

Villar, A., Pesun, I.J., Brosky, M.E., Fines, C., Hodges, J.S., DeLong, R., Lai, J.H. Clinical evaluation of a new resilient denture liner. Part 1: compliance and color evaluation. J Prosthodont. 2003;12:82-89.

Wegner, K., Zenginel, M., Buchtaleck, J., Rehmann, P., Wostmann, B. Influence of two functional complete-denture impression techniques on patient satisfaction: dentistmanipulated versus patient-manipulated. Int J Prosthodont. 2011;24:540-3.

Wendt, D.C. The degenerative denture ridge: care and treatment. J Prosthet Dent, 1974;32:477-92.

Winkler, S. Essentials of complete denture prosthodontics. ( $2^{\text {nd }}$ ed.). St Louis, MO: Mosbycity, state: publisher, 1989: 427-432, 441-455.

Wright, P.S. Composition and properties of soft lining materials for acrylic dentures. J Dent. 1981;9(3):210-223.

Wright, P.S. The success and failure of denture soft lining materials in clinical use. J Dent. 1984;12:319-327.

Wright, P.S. Observations on long-term use of a soft lining material for mandibular complete dentures. J Prosthet Dent 1994;2:385-392.

Yanikoglu, N.D., Duymus, Z.Y. Comparative study of water sorption and solubility of soft lining materials in the different solutions. Dent Mater. 2004;23:233-239.

Yap, A.U., Sim, C.P., Loganathan, V. Polymerization color changes of esthetic restoratives. Oper Dent. 1999;24:306-311.

Zarb, G.A., Bolender, C.L. Hickey, J.C., Carlsson, G.E. Boucher's prosthodontic treatment for the edentulous patient. St Louis, Mo: The CV Mosby Co, 1989:542-544. 


\section{VITA}

Dr. Morrell was born in 1978. He received his doctoral degree in dentistry (Doctorate of Medical Dentistry) from Temple School of Dentistry, Philadelphia, Pennsylvania, in 2009. He was accepted into the Advanced Prosthodontics Program at the University of Tennessee Health Science Center in 2009. Dr. Morrell is currently a third year resident, specializing in fixed and removable prosthodontics at UTHSC. He will be finishing his Master of Dental Science degree from the University of Tennessee. 